\title{
Analysis of economic potential areas based on farming agricultural sector in the border area of Sangihe Island Regency
}

\author{
Agustinus N. Kairupan ${ }^{1,{ }^{*}}$ and Conny Manoppo ${ }^{1}$ \\ ${ }^{1}$ North Sulawesi Assessment Institute of Agricultural Technology, Kalasey-Manado Agricultural \\ Campus
}

\begin{abstract}
Various potentials and challenges in agricultural development in the border region are expected to managed and overcome properly. The participation of all parties, is needed to support this sector. The purpose of study was to determine the basic food crop agricultural commodities that have fast growth and competitiveness in the border region of North Sulawesi. This study uses analytical methods with secondary data. The data analysis determined changes in the structure or performance of the regional economy against higher economic structures (provincial or national) is the location quotient analysis (LQ). To determine the performance or productivity of the work of the local economy by comparing it with the larger using Shift Share Analysis (SSA). The results showed that the most superior commodity and the base in the Sangihe Islands Regency was sweet potato with the LQ value of 12.64 , cassava 9.1 and peanut 2.96. The results of the Shift Share analysis show that the six agricultural commodities of food crops (lowland rice, dry rice, cassava, sweet potato, peanuts) have not been able to growth in the food crop agriculture sector because it has slow growth.
\end{abstract}

\section{Introduction}

Border area development is essentially an integral part of national development. Border areas have a strategic value in supporting the success of national development, this are indicated by the characteristics of the activity that is, it has an important impact on the sovereignty of the State and is a driving factor for improving the socio-economic wellbeing of the surrounding community. FKPR [2] said, border areas have great potential to be excavated in an effort to support increased food production, both in terms of area and quality of natural resources.

The border region which is included in the North Sulawesi Province is the Sangihe Islands Regency and the Talaud Islands, the outer sea borders that directly adjacent to the Philippines [5] As the gate and NKRI North Fortress has been designated a border area (article VII UU No $\mathbf{7 7}$ 1957), which is also designated as a Trans-boundary Trading Area (Article II Keppres No 6 1975). As the first priority location Management of State Boundaries and Border Areas in 2010-2014 is directed at the Sangihe Islands Regency,

\footnotetext{
*Corresponding author: audikairupan@gmail.com
} 
especially in the Marore Islands and surrounding areas (BNPP rules No $\underline{\mathbf{3} \mathbf{2 0 1 1}}$ about Action Plan for Management of State Boundaries and Border Areas).

Generally, the real conditions on the small islands and the border areas show unfavorable conditions that is still far from the attention of the government so that it becomes an area that is often overlooked and unoptimized [29]. Agricultural development in the border regions of the outer islands is relatively not received serious attention, even though the potential of this sector is immense in driving economic growth in the border region. Developing agriculture in the border region need a deep understandings because each region has diverse regional conditions and agricultural commodities. Under these conditions greatly affect the strategic and agricultural development policies in each of the border areas.

Populations in developing countries whose livelihoods depend on the agricultural sector are typically poorer than those working in other economic sectors. In general, it is a major population living in rural areas $[15,9]$. Globally, the rate of poverty has declined steadily, an achievement credited largely to economic growth. But what caused economic growth and how is the role of agricultural growth in poverty reduction is still a question to be answered [8, 15].

To strengthen the competitiveness of the national economy including the competitiveness of agricultural commodities, different clusters of regions are needed which in addition to considering the approach of the big islands also consider the border areas of both the land border and the borders of the outer minor islands [12]. The purpose of this study is to determine the basic food crop agricultural commodities that have fast growth and competitiveness in the border region of North Sulawesi.

\section{Methods}

The research area was taken intentionally (purposive method) that is in the Sangihe Islands Regency which one of the border areas or regions in North Sulawesi Province. This study used analytic methods, which was applying some analysis related to research by compiling data first, then analyzed and interpreted more deeply [23]. The secondary data were used, includes production data and harvested area of agricultural commodities for food crops at the Provincial and Regency levels, from 2011 to 2015. Data sourced from the Central Statistics Agency (BPS), Department of Agriculture and other related institutions.

Data analysis method was used to determine changes in the structure or performance of the regional economy to a higher economic structure (provincial or national) or is to find out which sectors in an area are superior / commodities and which sectors are not superior (negative growth / deficit) by comparing an area with the regions at its upper level over a certain period of time, such as location quotient (LQ) with the formula [26].

$$
L Q=(X i r / X r) /(X i n / X n)
$$

Explanation:

$\mathrm{X}_{\mathrm{ir}}=$ Regional Variable (commodity production) in $i$ sector in $j$ region (district)

$\mathrm{X}_{\mathrm{r}}=$ Regional Variable in region $r$

$\mathrm{X}_{\mathrm{in}}=$ Regional Variable in sector $i$ in $n$ region (province)

$\mathrm{X}_{\mathrm{n}}=$ Regional Variable in $n$ region

LQ $>1$, is the commodity sector (leading); LQ $<1$, meaning it is not commodity sector (deficit); $\mathrm{LQ}=\mathrm{O}$, meaning that there is only enough sector to fulfill needs of the area itself. $\mathrm{Xr}$ adalah sector $\mathrm{i}$ in the region; $\mathrm{Xr}$ is the total number sectors in the regions; $\mathrm{Xn}$ is sector $\mathrm{i}$ in the national; $\mathrm{Xn}$ is the number of all sectors national. 
The Shift Share Analysis (SSA) determined the performance or productivity of the work area of the economy by comparing it to the larger one (regional or national level. The outcome of these calculations show indicators of competitive ability [3], the model of the equation is as follows:

$$
D S i j=X i j(t 1) / X i j(t 0)-X i(t 1) / X i(t 1)
$$

Explanation:

$\mathrm{X}_{\mathrm{ij}} \quad$ : Production of a certain commodities (i) in a district (j)

$\mathrm{Xi} \quad$ : Total production of commodities (i) in province

t1 : Final year point $(2015)$

t0 : Starting year point (2011)

The result of the analysis are interpreted;

If the value of shift share $>1=$ shows that sector growth at the regional level one is faster than sector growth in the second region (comparative region), while the value of shift share $<1$ = shows that growth at the level of region one is slower that the growth of the sector at second area (comparison).

[28], They said that "Shift share is a descriptive analytical tool and technique for the regional economic analysis". Shift share analysis also used to compare the differences in growth and employment across regions. The employment change is happened owing to national trends, local conditions and industrial sector trends. Shift share analysis is very popular among the geographers, regional scientists and planners. [27] stated that the implementation of regional shift-share approach for examining the economic performance of the East Cost Economic Region (ECER) of Malaysia compared to the performance of the national economy.

\section{Results and discussion}

\subsection{General conditions of reasearch areas}

Geographically, the Sangihe Islands Regency is an integral part of the North Sulawesi Province with its capital Tahuna. Located about 142 Mil across the sea from the capital of North Sulawesi Province, Manado, it is located between 20'4'13', - 40 44' 22' North Latitude and 1250 9' 28', - 1250 56' 57' East Longitude. Have boundaries: North Republic of the Philippines and Regency of the Talaud Islands; South - Sitaro Regency; East - Pacific Ocean and Molucas Sea; West- Sulawesi Sea. The total area of $736.98 \mathrm{~km} 2$ which is divided into15 districts. North Tabukan is the largest area district, which is 114.76 $\mathrm{km} 2$ (15.57 percent of the total area of Sangihe Islands District).

According to the geographical position, topography, and biophysical factors of the border region, climatic or agroclinical conditions of the border region are very diverse. As is common in Indonesia, all border areas have a wet tropical climate (humid tropic) with a noticeable difference in the rainy season and dry season. In general, the average monthly temperature measurement from Naha Meteorological Station is $27.8^{\circ} \mathrm{C}$, where the lowest temperature is $20.0^{\circ} \mathrm{C}$ in March, and the highest temperature is $34.0^{\circ} \mathrm{C}$ in July.

Rainfall is influenced by climate conditions, geographical conditions, and velocity or confluence of air currents. Therefore rainfall varies by month. Rainfall patterns are mostly monsoons that are exponential with rain peaks around December January, or with rather diverse local patterns. Equatorial patterns are found around the equatorial zone with 
bimodal rainfall patterns (two peaks).The highest rainfall during 2016 occurred in November which was $465 \mathrm{~mm}^{3}$ with 24 rain days, while the lowest rainfall occurred in March, which was $40 \mathrm{~mm}^{3}$ with 16 rainy days.

Border areas are characterized by low and uneven population density in relatively large areas [1]. Furthermore, it is also said that, the population density in the border area averages about 39 people $/ \mathrm{km} 2$, much lower than the population density in non-border areas reaching 183 people $/ \mathrm{km} 2$. The population of Sangihe Islands Regency in 2016 based on the results of population projection is 130,024 people with a total number of households as much as 34,040 and a population density of 176.43 people $/ \mathrm{km}^{2}$, North Tabukan District have the highest population of 15.15 percent of the total population in Sangihe, and the largest population density is in Tahuna District as the capital of Sangihe Island Regency, which is 717.39 people $/ \mathrm{km}^{2}$. [24] said, in the context of building agriculture in a region, the ability to human resources play a very important role; Good quantity and quality. In terms of quantity, the number of people (population) will have a significant impact on the ability to purchase products especially food products, and in terms of quality is very influential the ability to absorb and implement agricultural technology innovations and the implementation of good agricultural management.

According to some research, one of the reasons for low productivity in the agricultural sector is that agriculture still in the subsistent stage. Most of the output consumed by farmer's family, agricultural output and productivity are low due to the utilization of traditional methods and tools, Farmers' unwillingness to adopt new technology due to the lack of capital, higher energy prices, food crisis issues and sustainable development issues. [22]. Agriculture not only provides resources to nonagricultural sectors, but also agriculture is substantial market for industrial products that helps modernize traditional production techniques by providing modern inputs, technology, and improve managerial skills. Eventually though both the agricultural and industry benefit from each other but thereby increases productivity in the whole economy. [13].

\subsection{Food crop production sector results in North Sulawesi province}

Some studies show that food crop commodities have a comparative and competitive advantage in regional development [25]. In addition, several studies [5] shows that some food crops can become a superior commodity in a region. Data on the production of agricultural food crops (lowland rice, dry rice, corn, cassava, sweet potatoes, and peanuts) in the North Sulawesi Province from 2011 to 2015, as shown in Table 1.

Table 1. Data on production results (tons) in the food crop agriculture sector in North Sulawesi Province 2011 - 2015.

\begin{tabular}{|c|c|c|c|c|c|c|c|}
\hline \multirow{2}{*}{ Year } & \multicolumn{6}{|c|}{ Commodities } & \multirow{2}{*}{ Total } \\
\cline { 2 - 7 } & $\begin{array}{c}\text { Lowland } \\
\text { Rice }\end{array}$ & $\begin{array}{c}\text { Dry } \\
\text { Rice }\end{array}$ & Corn & Cassava & $\begin{array}{c}\text { Sweet } \\
\text { Potatoes }\end{array}$ & Peanuts & Tol \\
\hline 2011 & 566.262 & 29.975 & 438.504 & 70.147 & 46.266 & 9.049 & $1,160.203$ \\
\hline 2012 & 580.263 & 34.799 & 440.308 & 63.187 & 41.227 & 8.247 & $1,168.031$ \\
\hline 2013 & 604.148 & 34.225 & 448.002 & 55.207 & 39.8 & 8.247 & $1,189.629$ \\
\hline 2014 & 587.009 & 50.918 & 488.362 & 46,553 & 39.429 & 7.069 & $1,219.340$ \\
\hline 2015 & 634.890 & 39.279 & 300.49 & 44.123 & 25.705 & 3.971 & $1,048.456$ \\
\hline $\begin{array}{c}\text { Land Area } \\
\text { (Ha) }\end{array}$ & 113.842 & 15.030 & 114.143 & 4.345 & 3.911 & 5.645 & \\
\hline
\end{tabular}

Source: BPS, North Sulawesi Province in Figures for 2011 - 2015, BPS, North Sulawesi Agriculture Statistics 2015 
In general, the production of the agricultural food sector in North Sulawesi Province in 2015 (Table 1) showed a decrease compared to 2014, except for lowland rice. Lowland rice commodity increased by $7.54 \%$. At the same time, the others experienced a decrease, Dry Rice $(29.63 \%)$, corn $(62.52 \%)$, cassava $(5.51 \%)$, and sweet potato $(53.39 \%)$, peanuts (78.02\%). Land area is an important component to increase production. Various factors influence the decision making for agricultural land use in an area. These factors can be physical factors such as climate, temperature (heat) and; rainfall [19, 21] topography; reliefs and rocks; soil; nutrients / fertility and soil physical characteristics; water; water potential, depth [20].

Three factors for explain the decline of the agricultural sector have been provided: change in the terms of trade (or relative price) of agricultural products; differential sectoral technical change and factor productivity growth rates; change in factor endowment, i.e., of capital and land intensity (per unit of labor) [14].

\subsection{Food Crops Agricultural Sector Production Results in Sangihe Islands}

Data on production from the agricultural sector of food crops (lowland rice, field rice, maize, cassava, sweet potatoes and peanuts) in Sangihe Islands District from 2011 to 2015, is shown in Table 2 .

Table 2. Data on Production (ton) of Food Crops Agriculture Sector in Sangihe Islands District, $2011-2015$.

\begin{tabular}{|c|c|c|c|c|c|c|c|}
\hline \multirow[b]{2}{*}{ Year } & \multicolumn{6}{|c|}{ Commodities } & \multirow[b]{2}{*}{ Total } \\
\hline & $\begin{array}{l}\text { Lowlan } \\
\text { d Rice }\end{array}$ & $\begin{array}{l}\text { Dry } \\
\text { Rice }\end{array}$ & Corn & Cassava & $\begin{array}{c}\text { Sweet } \\
\text { Potatoes }\end{array}$ & Peanuts & \\
\hline 2011 & 244.7 & 171.85 & 856.7 & 4101.75 & 3526.24 & 154.56 & $9,055.8$ \\
\hline 2012 & 184.6 & 96.75 & 618 & 2997 & 3544 & 154.56 & $7,594.91$ \\
\hline 2013 & 22 & 30 & 40.65 & 1073.85 & 738.85 & 16.35 & $1,921.70$ \\
\hline 2014 & 130 & 46.5 & 197.5 & 1298.1 & 1283.28 & 36 & $2,991.38$ \\
\hline 2015 & 104 & 22 & 63 & 296 & 349.5 & 58.5 & 893 \\
\hline $\begin{array}{c}\text { Land } \\
\text { Area }(\mathrm{Ha})\end{array}$ & 1248.72 & 45.538 & 126.9 & 298.18 & 305.38 & 48.64 & \\
\hline
\end{tabular}

Source: BPS, Sangihe Islands District in Figures for $2011-2015$

Production in the agricultural sector of food crops in Sangihe Islands Regency in 2015 (Table 2), generally showed a decrease compared to 2014, except for peanuts. The peanut commodity increased by $38.46 \%$. While others experienced a decline, namely lowland rice $(25 \%)$, dry rice $(111.36 \%)$, corn $(213.49 \%)$, cassava $(338.54 \%)$ and sweet potatoes $(267.17 \%)$. According to the production and supply theories, production growth in a sector would be possible in two ways; the use of more production factors and the use of more technologies. In Iran and several other developing countries, the limitation of water and agricultural inputs restricts the first way of increasing production in the long-run [1].

\subsection{Location quatien (LQ) analysis}

Building the competitiveness of small islands is different from the competitiveness of the big islands, not only in the differences in biophysical, socioeconomic and cultural conditions but because of the character of the small island itself which does not easily apply and expand innovation as well as the big islands due to the constraints of the area and demographic area [11]. The competitiveness of food commodities in the border region can be realized through three approach, namely production efficiency, selection of commodity 
types to be developed, and improve the quality of results through development of intensive, even modern, agricultural systems that supported by downstream innovation and superior technology.

Data on production (tons) and land area (ha) of the food crop agriculture sector in Sangihe Islands Regency and North Sulawesi Province can be seen in Table 3.

Table 3. Production result (ton) and land area (ha) food crop agriculture sector in Sangihe Islands Regency and North Sulawesi Province

\begin{tabular}{|l|c|c|c|c|}
\hline \multirow{2}{*}{ Commodities } & \multicolumn{2}{|c|}{$\begin{array}{c}\text { Sangihe Islands } \\
\text { Regency }\end{array}$} & \multicolumn{2}{c|}{$\begin{array}{c}\text { North Sulawesi } \\
\text { Province }\end{array}$} \\
\cline { 2 - 5 } & $\begin{array}{c}\text { Production Result } \\
\text { (ton) }\end{array}$ & $\begin{array}{c}\text { Land Area } \\
\text { (ha) }\end{array}$ & $\begin{array}{c}\text { Production Result } \\
\text { (ton) }\end{array}$ & $\begin{array}{c}\text { LandArea } \\
\text { (ha) }\end{array}$ \\
\hline Lowland Rice & 685.30 & 1248.72 & $2,972.57$ & 113.842 \\
\hline Dry Rice & 367.10 & 45.538 & 189.20 & 15.030 \\
\hline Corn & $1,775.85$ & 126.9 & $2,115.67$ & 114,143 \\
\hline Cassava & $9,766.70$ & 298.18 & 279.22 & 4.345 \\
\hline Sweet Potatoes & $9,441.87$ & 305.38 & 192.43 & 3.911 \\
\hline Peanuts & 419.97 & 48.64 & 36.58 & 5.645 \\
\hline Total & $22,456.79$ & & $5,785.66$ & \\
\hline SOyyyy
\end{tabular}

Source: BPS, North Sulawesi Province in Figures for 2011 - 2015, BPS, North Sulawesi Agriculture Statistics 2015

Regional development planning from the aspect of agricultural development is the determination of the role of superior commodities to achieve agricultural development targets namely growth. According to I. Martadona (2019), the ability to spur the growth of a region depends heavily on the excellence or competitiveness of agricultural commodities in its region. The results of the location quotient (LQ) analysis of the production of food crops sector in Sangihe Islands Regency and North Sulawesi Province, are shown in Table 4.

Table 4. Location Quatien (LQ) Results of Food Crops Sector Production

\begin{tabular}{|l|c|c|c|}
\hline \multirow{2}{*}{ Commodities } & Sangihe IslandsRegency & North SulawesiProvince & $\begin{array}{c}\text { Location } \\
\text { Quatien } \\
\text { (LQ) }\end{array}$ \\
\cline { 2 - 3 } & Production Results (ton) & Production Results (ton) & 0,06 \\
\hline Lowland Rice & 685.30 & $2,972.57$ & $-0,5$ \\
\hline Dry Rice & 367.10 & 189.20 & 0,22 \\
\hline Corn & $1,775.85$ & $2,115.67$ & 9,1 \\
\hline Cassava & $9,766.70$ & 279.22 & 12,64 \\
\hline Sweet Potatoes & $9,441.87$ & 192.43 & 2,96 \\
\hline Peanuts & 419.97 & 36.58 & \\
\hline Total & $22,456.79$ & $5,785.66$ & \\
\hline
\end{tabular}

Source: Data Analysis Results (2019)

Based on the analysis results in Table 4, it can be seen that the food crops sector of cassava, sweet potatoes and peanuts being commodity based has LQ value $>1$ reaching 9.1 for the cassava, 12.64 for sweet potatoes and 2.96 for peanuts. This shows that the results of those three food crop commodities (cassava, sweet potatoes, and peanuts) can meet the demands in Sangihe Islands Regency and are expected to be able to encourage the growth of other economic sectors so as to increase the economic growth rate of the region. Whereas lowland rice, dry rice, and corn commodities are not superior commodities in Sangihe Islands Regency because they have LQ value $<1$. The LQ value for lowland rice is 0.05 , dry rice -0.5 , and corn 0.22 . This shows that the three food crop commodities cannot 
meet the needs of Sangihe Islands Regency. [10] stated, the development of agricultural commodities in the border area should be projected on activities and businesses capable of delivering high economic benefits, technically efficient, not environmentally polluting, and culturally tolerant.

\subsection{Shift share analysis (SSA)}

The Shift Share Analysis (SSA) results of the food crop agriculture sector production are seen in Table 5.

Table 5. Shift Share Analysis (SSA) Results of The Food Crop Agriculture Sector Production

\begin{tabular}{|l|l|l|l|}
\hline \multirow{2}{*}{ Commodities } & $\begin{array}{l}\text { SangiheIslands } \\
\text { Regency }\end{array}$ & $\begin{array}{l}\text { North Sulawesi } \\
\text { Province }\end{array}$ & $\begin{array}{l}\text { Shift } \\
\text { Total }\end{array}$ \\
\cline { 2 - 3 } & Production Results(ton) & ProductionResults(ton) & \\
\hline Lowland Rice & 685.3 & 2972.572 & $-170,36$ \\
\hline Dry Rice & 367.1 & 189.196 & $-203,19$ \\
\hline Corn & 1775.85 & 2115.666 & -524.06 \\
\hline Cassava & 9766.7 & 279.217 & $-2284,03$ \\
\hline Sweet Potatoes & 9441.87 & 192.427 & $-1609,65$ \\
\hline Peanuts & 419.97 & 36.583 & $-9,3$ \\
\hline Total & $22,456.79$ & $5,785.66$ & \\
\hline SOan
\end{tabular}

Source: Analysis Results Data (2019)

In Table 5 the Shift Share results shows that those six agricultural commodities of food crops got negative value (-), where the lowland rice commodity is -170.36 , dry rice -203.19 , corn -524.06 , cassava -2284.03 , sweet potatoes -1609.65 , and peanuts -9.33 . This shows that six commodities cannot trigger growth in the food crop agriculture sector because it has slow growth. Las [2] said, exclusive food commodities that are unique and charged with local wisdom with a certain economic value, must be maintained and developed, regardless of efficiency, productivity, and competitiveness aspects.

\section{Conclusion}

Based on the analysis of agricultural commodities in the border region of the Sangihe Islands Regency produces different base commodities. The food crop commodities that become the base commodities are sweet potato, cassava, and long beans. As for the lowland rice, dry rice and corn, it does not become a superior or non-base food crop. However, the results of the Shift Share Analysis showed that those six agricultural commodities of food crops (Lowland rice, dry rice, cassava, sweet potatoes, and peanuts) have not been able to trigger growth in the food crop agriculture sector because it has slow growth.

\section{References}

1. Amini, P. V., Shahabinia, A., Jafari, H., Karami, O., \& Azizi,. Environmental Research, 6 (12), 173 -182 (2016).

2. A.R. Sulaiman, I. Las, K. Subagyono, T. Alihamsyah, Hermanto. Balitbangtan. IAARD Press (2018)

3. Blakely, EJ and Leigh, NG.. Theory and Practice. 4th Ed. Sage Publication (2010)

4. Baladina N, R. Anindita, R. Isaskar, Sukardi. J.AGRISE. 13(1):30-41 (2013) 
5. Badan Pengelolah Perbatasan Propinsi Sulawesi Utara (2012)

6. Badan Pusat Statistik.. BPS Kabupaten Kepulauan Sangihe (2012-2015)

7. Badan Pusat Statistik. BPS Provinsi Sulawesi Utara (2015)

8. Cervantes-Godoy, D., Dewbre, J. Development 27. doi:10.1787/5kmmv9s20944-en (2010)

9. Diao, X., Hazell, P., Thurlow, J. World Dev, 38, 1375-1383. doi:10.1016/j.worlddev.2009.06.011(2010).

10. D. Parhusip, L. Haloho, K.L. Ramija.. Buku. IAARD Press Pp31-47. (2019)

11. E. Pasandaran,.; E.E., Ananto; K. Suradisastra; N.S. Saad dan B. Irawan. Balitbangtan. IARRD Press. Jakarta (2014)

12. E. Pasandaran dan Suherman. Buku. IAARD Press .Pp: $481-506$ (2015) http://www.litbang.pertanian.go.id/buku/memperkuat_dayasaing_produk_pe/BAB-IV3.pdf

13. Eddine Chebbi, Houssem (2010), Agriculture and economic growth in Tunisia, China Agricultural Economic Review, Vol. 2, No. 1, pp. 63-78.

14. Esposti, Roberto. Structural Change and Economic Dynamics, Vol. 31, pp. 73-88 2014)

15. FAO (Food and Agriculture Organization). fact sheet food Agric. policy trends 717, 6 . doi:I5890E/1/07.16 (2014)

16. I. Martadona. MI. Vol. XIII. No. 3. (2019.) https://jurnal.umsb.ac.id/index.php/menarailmu/

17. J. Herath, T.G. Gebremedhin and B.M. Maumbe.. JR and C. 6 (2) : 155-169 (2011)

18. Karami, O., Saleh, I., Rafiee, H., \& Hosseinpour, N. Environmental Research, 7(13),85-92.(2016)

19. Kawasaki, Jintana., and Srikantha Herath. J. Issaas Vol. 17, No. 2:14-28 (2011).

20. Klocke, N.L., and Currie R.S. Available from CPIA, 760 N. Thompson, Colby, Kansas (2011).

21. Lucas, B., and S.. The Scandinavian J of E, vol. 113, No. 4, pp. 825-845 (2011)

22. Matahir, H., \& Tuyon, J. International JEF 5(4),61 (2013)

23. M. Nazir.. Bogor: Ghalia Indonesia (2019)

24. M. Nunuela, M. Thamrin. 2019.. Buku. Pp: 255-270. IAARD Press (2019)

25. O. R. Nindhitya. ED A J. 2(1): 01-08 (2013)

26. Putra, M.F. Universitas Brawijaya (UB) Press, Cetakan Pertama, April, Malang. (2011)

27. Rashid, \& Hamid. stated that the implementation of regional shift-share approach for examining the economic performance of the East Cost Economic Region (ECER) of Malaysia compared to the performance of the national economy (2011)

28. StejskaL, J.: Průmyslové klastry a jejich vznik v regionech. 1st ed. Praha: Linde, 247 pp (2011)

29. Y.A. Dewi, A. Hendradi, E.E. Ananto, Balitbangtan. IAARD (2013) 